\title{
BORN TO FAIL? POLICING, REFORM AND NEIGHBOURHOOD PROBLEM SOLVING
}

\author{
DR KAREN BULLOCK \\ Lecturer, Department of Sociology, University of Surrey, Guildford \\ NICK TILLEY \\ UCL Jill Dando Institute of Crime Science, University College London
}

\begin{abstract}
The issue of problem solving as a component of neighbourhood policing is an important and potentially highly problematic one. The UK government claims in its 2008 Green Paper, From the Neighbourhood to the National, to be 'absolutely committed to neighbourhood policing as the bedrock for local policing in the 21st Century'. Yet experience tells us that implementation of problem solving is likely to be far from straightforward. This article draws attention to the many obstacles identified over 25 years of experimentation with the principles of problem solving. The article examines what is known about implementation of problem solving in the police service and the factors which influence its delivery. It draws attention to lessons learnt and the implications for the delivery of neighbourhood policing.
\end{abstract}

Keywords: implementation; neighbourhood policing; problem-oriented policing

\section{Introduction}

It is necessary to be clear-eyed about the difficulties of innovating in police organisations. Because of widespread enthusiasm for innovations, such as community and problem-oriented policing, third-party policing, 'lever-pulling' policing, and evidence-based policing amongst academics, it could appear that reform comes easily. In fact, it is hard, the political risks involved are considerable, and efforts to change the police often fall far short or fail. (Skogan, 2008)

Few statements could be truer. Wesley Skogan is a seasoned police researcher who has observed in detail the ups and downs of Chicago's efforts at police reform for more than a decade. He captures well the disappointments etched also on the faces of many of his less distinguished counterparts, among whom we count ourselves who have looked empirically at what has happened in practice in attempts to introduce innovations for improving policing.

The Labour Government from 1997 has been committed to reform of the police. A key feature of this agenda in England and Wales has included the roll-out of 'neighbourhood policing' principles throughout England and Wales. The neighbourhood policing framework provides for a great deal of local flexibility. Nevertheless, three generic requirements are stressed. These are:

1. The consistent presence of dedicated neighbourhood teams which are visible, accessible, skilled and familiar to the community. 
2. Intelligence-led identification of community concerns along with prompt, effective, targeted action to tackle these concerns.

3. Community-focused problem solving drawing in other local partners: the community should be involved in the identification of problems and delivery of interventions. Multiple sources of information should be rigorously analysed. (ACPO/Centrex, 2006)

This article focuses in particular on the last of these: the role of problem solving in neighbourhood policing. We have spent many years observing attempts to implement problem solving in the UK and beyond, as well as supporting them. One of us was involved in the original attempts to embed problem-solving principles in pilot areas in England and evaluated its impact (see Leigh et al., 1996; 1998). Both of us were involved in the England and Wales HMIC problem-solving inspection in 2000 (see HMIC, 2000; Read \& Tilley, 2000) and in the implementation of the Labour Government's $£ 32 \mathrm{~m}$ 'targeted policing initiative' which funded experiments and evaluation of problem-solving projects (see Bullock \& Tilley, 2003).

The government claims to be 'absolutely committed to neighbourhood policing as the bedrock for local policing in the 21st Century' (Home Office, 2008). Yet experience tells us that implementation of problem solving is likely to be far from straightforward. This article draws attention to the many obstacles identified over 25 years of experimentation with the principles of problem solving. Drawing on our experience and a wide-ranging review of the literature in this area, the article spells out what is known about implementation of problem solving in the police service and the factors which influence its delivery. It draws attention to lessons learnt and the implications for the delivery of neighbourhood policing.

\section{Neighbourhood Policing, Problem Solving and Problem-Oriented Policing}

The issue of problem solving as a component of neighbourhood policing is an important and potentially highly problematic one. It is clear that 'visibility' and 'familiarity' of policing (point 1 above) are not likely to produce desirable outcomes on their own (Innes, 2005; Tuffin et al., 2006). Indeed in their evaluation of the National Reassurance Policing Programme1 (on which neighbourhood policing draws) Tuffin and colleagues conclude that

visibility and familiarity cannot deliver shifts in public perception on their own, according to this evidence. The evidence here supports a local policing approach which incorporates three elements, engagement, problem-solving and visibility through patrol. (2006: 94)

Reflecting this, it is widely recognised (in official documentation and guidance on the roll-out of neighbourhood policing) that the provision of visible police officers locally will not on its own reduce crime or improve public confidence in policing and may in fact contribute to public concerns about crime and disorder (Innes, 2005). The implication is that attention needs to be paid to the delivery of high-quality problem solving.

The principles of problem solving in the policing context are rooted in the model described by Goldstein $(1979 ; 1990)$. Goldstein's premise is that the core of policing should be proactive rather than reactive and that the business of the police service should be to understand and prevent problems recurring, rather than to react to 
criminal events as they occur. The concept which Goldstein described as 'problemoriented' involves:

1. The identification of problems through systematic grouping of recurring incidents, recognising links between them, and an attempt to understand how and why these sets of incidents arise. Police officers should seek to understand a problem though looking at it in detail drawing on a range of sources.

2. Responses to identified problems should be tailored to the explanations of why that problem exists. Attention should be focused on a specific aspect of the problem seemingly amenable to intervention. In particular the police service should be looking to expand its responses beyond its normal remit of law enforcement, seeking the best way to develop responses to a whole range of problems which may draw in the resources of non-police agencies.

3. The new response should be monitored and evaluated to ensure that one ineffective response is not merely replaced with another and to guard against a response simply reverting to its older form.

Reflected in the neighbourhood policing literature and guidance the term 'problem solving' has become widely used in UK policing. 2 The link between Goldstein and problem-orientation is generally acknowledged (Read \& Tilley, 2000) and the frameworks associated with the implementation of problem-oriented policing are often used to focus problem-solving work (as with neighbourhood policing; see ACPO/Centrex, 2006).

The following points highlight key activities involved in neighbourhood policing and problem-oriented policing, noting both overlaps and also some important differences between them:

1 The systematic identification and prioritisation of crime (and other) problems which are important to the community. The starting-point of neighbourhood policing is the identification and prioritisation of problems which communities consider to be harmful. For Goldstein (1990) the views of the community should not be the only basis on which problems are prioritised but problems identified for preventive action should be of concern to the community.

2 Rigorous analysis of problems drawing on a wide range of data. Rigorous analysis of problems is the driver of problem-oriented policing. Without this, problems are unlikely to be understood and responses are unlikely to be successful. This is reflected in the reassurance policing agenda. Tuffin and colleagues (2006) found that those areas which showed a significant positive change in public perceptions of juvenile nuisance were those where there appeared to have been analyses drawing on multiple sources of information, producing detailed specifications of the problem in terms of two (and sometimes all three) sides of the crime triangle (location, victim, offender).

3 Drawing in resources from other agencies and the community. Neighbourhood policing stresses joint action with communities and partners to solve problems. Goldstein stressed the need for the best response, which may not always involve the police directly and may include those from other sections of the community. For problem-oriented policing community involvement in addressing a crime problem is not an essential requirement. For some (perhaps many) problems community involvement of some sort may comprise an 
element of an intervention, but this will not necessarily always be so (Bullock et al., 2006).

4 Evaluation and dissemination of results. Goldstein (1990) stressed the role of systematic evaluation as central to problem-orientation. The neighbourhood policing framework makes less of the requirement for evaluation but nevertheless HMIC (2008: 39) calls for 'proportionate evaluation of joint problem solving reporting promptly (on what the problem is, response, impact and outcome, and feeding back to the originator)' and for sharing of knowledge regarding what is effective in tackling local problems.

Whilst neighbourhood policing is a key aspect of police reform it is, at the time of writing, relatively new. Yet there is now a long history of implementing problemoriented policing in the UK and elsewhere. The principles of problem solving are seen as common sense by many, but efforts to deliver broad-based problem solving across police services have generally fallen short of expectations and the literature is littered with examples of failed projects and disappointment. It is generally agreed that highquality problem-oriented policing is rare and a reading of the literature suggests that problems with delivering this approach have been considerable (Leigh et al., 1996, 1998; Read \& Tilley, 2000; HMIC, 2000; Scott, 2000; Knutsson, 2003; Bullock \& Tilley, 2003; Cordner \& Biebel, 2005; Bullock et al., 2006):

1. It is common for analysis to be missed out all together. Where it is conducted it can lack rigour and specificity and there is a focus on police-generated data. High-quality analysis is the essential driver of problem solving and without it, problems are unlikely to be understood and any interventions will be unsuccessful.

2. It is common for problems to be inadequately defined and disaggregated for the purpose of analysis. Broadly defined problems have led to poorly focused responses that are too ambitious.

3. Rather than being based on what is known to be effective in tackling problems, police officers do not appear to take account routinely of the literature on crime reduction when developing responses to problems. In developing responses officers tend to rely on personal experience and informal discussions with other officers.

4. Police officers continue to rely on conventional policing responses such as high-visibility policing, arrests and incapacitation in addressing problems.

5. The involvement of other agencies in delivering responses has been limited.

6. Whilst evaluation of interventions is viewed as important, it is rarely well done.

\section{Factors Shaping the Delivery of Problem-Oriented Policing \\ Organisational}

Problem solving as an organisational strategy has floundered where there is no strong leadership (Read \& Tilley, 2000; Skogan, 2008). Strong leadership both facilitates access to the resources required and conveys clear messages to the organisation about the ways in which policing should be being done. The delivery of problem-oriented policing challenges the prevailing reactive status quo and so authority to implement a new style is required (Scott, 2006). 
The rank-based hierarchical and bureaucratic nature of the police service and particularly the formalised accounting systems that are associated with it are unsuited to problem-solving approaches. Police organisational structures have typically been based on quasi-military lines and organised to facilitate reactive, emergency-driven policing (Goldstein, 1990; Brown \& Sutton, 1997). This hierarchy with centralised policy making and top-down, risk-averse management structures have been considered to conflict with the more flexible kinds of structures which are required to facilitate the delivery of problem-oriented policing (Eck \& Spelman, 1987; Leigh et al., 1996; Skogan, 2008).

Closely related, conventional policing performance management systems tend to be based on response times, arrests and detection rates, but commentators have suggested that these are not effective for holding officers to account for success in dealing with community-based problems and for implementing problem-oriented policing (Braga, 2002). Like others, Metcalf (2001) agrees that the police service has primarily been concerned with the achievement of measurable objectives (such as numbers of arrests or detections) rather than with the processes through which policing is conducted, which, she argued, is essential for implementing problemoriented policing. She went on to argue that whilst there has been an acknowledgement that policing styles would have to change to facilitate problemoriented policing, this has not happened in practice. This might be because it is easier for police supervisors to measure outputs such as arrests rather than the flexibility and creativity called for in solving problems (Metcalf, 2001). Goldstein (1990) similarly argued that routinised jobs are easier to supervise than those that require flexibility and creativity. However, in the absence of suitable performance measurement indicators, it is difficult to motivate officers to change the way that they conduct policing (Braga, 2002). Indeed, implementation of problem-oriented policing in the Metropolitan Police Service in the early 1980s appears to have petered out because their management structure was out of step with the approach and adopting it would have involved taking more risks and abandoning some of the traditional expectations of line management (Leigh et al., 1996, drawing on Hoare et al., 1984).

\section{Technical Skills}

Given the key role of analysis in formulating problem-oriented responses, it is not surprising that the analytic capacity of police services has been shown to be important in shaping the nature of implementation. Studies have highlighted issues relating to the availability and quality of data, software and skilled personnel to conduct analyses.

Scott (2000) argued that good analytic systems were often lacking within police services. Moreover, the understanding of data within the police service has, he suggests, generally been poor. Moreover, police databases often are not designed with the need for systematic analysis in mind. Bullock and colleagues (2002) described a range of problems associated with trying to use many police databases for problemoriented policing. These include: failures to collect or record data relating to many attributes of incidents, victims and offenders; inaccurate entry of data by police officers and other staff; failures to enter data relating to many fields that are theoretically available; coding weaknesses, including entry of more than one variable in a single field; maintenance of records only in standard aggregate form; use of paper rather than computerised records; and adoption of systems to store data that may not be compatible with standard, flexible analytic software such as Excel or SPSS. Finally, changes in recording practices, for example Home Office ethical recording standards 
which were introduced in April 2002 (see Home Office, 2000), have also caused difficulties in tracking crime trends over time.

Studies have also shown that there have been difficulties in sharing information between agencies, which help to explain the observed reliance on police data in the analysis stages of problem-oriented policing. A persistent obstacle to the exchange of data has been the interpretation of data protection legislation by practitioners (Bullock et al., 2002; Irving \& Dixon, 2002). Drawing on a 2001 study, Irving and Dixon (2002) argued that, notwithstanding the provisions of the 1998 Crime and Disorder Act, data sharing within the community safety arena is in its infancy. Even where data sharing is agreed in principle, however, Bullock and colleagues (2002) note further practical difficulties, where crime and incidents are not coded to a specific point or are geocoded to different boundaries. For example, police data are usually organised around beats and basic command unit areas whilst local authority data are often organised by electoral wards. Moreover, similar information is often not collected and where it is collected it is often coded in different ways.

\section{Teaching the Principles and Developing Skills}

Training for officers who may find it hard to translate the concepts of problemoriented policing into everyday practice is important. Goldstein (1990) argued that a commitment to problem-oriented policing should pervade all training and that there should also be an attempt to hire people with the relevant skills and qualities needed to deliver it. However, the availability for training in problem-oriented policing appears to be patchy and lack of training may be a barrier to its implementation. Read and Tilley (2000) found that across the UK the provision of training was very variable, with some police service areas offering training in problem-oriented policing for all officers and some offering none at all. With this variation in availability of training it is perhaps not surprising that evidence suggests many officers struggle to understand the principles of problem-oriented policing and this in turn inevitably influences what is delivered in practice.

\section{Engaging Partners}

Significant efforts have been made to engage non-police partners in crime prevention activity. Crime prevention in partnership has been advocated officially since 1984, when Home Office Circular 8/84 was issued. Between then and 1998 encouragement continued to be offered, for example through Home Office Circular 44/90 and through the funding provided for the Safer Cities Programme, which ran from 1988 till 1998. The Crime and Disorder Act 1998 made partnership in crime reduction a statutory duty for police, local authority departments, the probation service and health services. The Crime Reduction Programme, which ran from 1999 to 2002, made available some $£ 400$ million, nearly all of which was aimed at partnership-based crime prevention and community safety initiatives (Homel et al., 2005). The principles of partnership working may be straightforward and convincing, but the practice of engaging agencies to work in partnership with the police service has been problematic.

Studies since the 1998 Crime and Disorder Act have shown that certain agencies have resisted the call to work with the police to prevent crime, especially the probation service and the health service (e.g. HMIC, 2000; Irving et al. 2001); the outcomes of joint initiatives have been disappointing with high ratios of talk to action and delays in delivering outputs (e.g. Byrne \& Pease, 2003); and practical difficulties, to do with such issues as data sharing, technical capacity, expertise in crime auditing, 
consultation and target setting, have limited what partnerships could achieve in practice (e.g. Gilling, 2005, drawing on Phillips et al., 2002).

\section{Dissemination of knowledge}

Studies have shown that officers have preferred to rely on their own knowledge and that of their colleagues and on conventional policing methods rather than look more widely for solutions to problems. It has been argued that this tendency to rely on traditional police responses occurs, at least partly, because police officers do not have the capacity and experience to develop and implement other kinds of responses. For example, Brown and Sutton (1997) argued that officers found it hard to see law enforcement as just one of a potential range of responses to problems. Eck (2003) similarly argued that, whilst not necessarily ineffective, conventional law enforcement responses to problems (such as arrests and prosecution) are probably overused because police officers are unclear about what the alternatives are. Many authors have pointed to the importance of a collective body of knowledge on how to tackle crime problems as a means of facilitating the delivery of problem-oriented responses (Scott, 2000; Irving \& Dixon, 2002; Eck, 2003; Goldstein, 2003; Townsley et al., 2003). Yet, the supply of relevant research is limited, and it is not surprising in these circumstances that officers tend to resort to conventional responses and folk wisdom. As Scott puts it,

While there is more relevant research on some community problems than many police officers realize, it is far less than one might expect given how common many problems are and how many public resources are spent trying to address them. There simply isn't enough quality research conducted to reliably inform the police about what does and does not work with respect to most crime and disorder problems. Outside of a few specialized areas that have received substantial research interest, the body of applied research on crime and disorder problems is not large. Again, compared to the body of literature in most other professions, the amount of published research about common community problems seems miniscule. (Scott, 2000: 64)

\section{Local Coordination and Project Management Skills}

General issues related to the availability of suitable staff for problem-oriented work have been highlighted. These include difficulties in recruiting and retaining project managers and other staff to implement project interventions once they have been developed (Brown, 2006). Brown (2006) argued that project management is an essential element in the implementation of problem-oriented projects, but there have been problems which include shortages of project management skills, difficulties in recruiting suitable individuals (which are often related to unattractive short-term contracts) and the length of time for recruitment in the public services. Bullock (2002) similarly argued that a high level of turnover of personnel in problem-oriented projects was common. They argued that this reduces enthusiasm and momentum for projects, promotes a lack of ownership and, on a practical note, creates delays as time is spent trying to recruit new staff.

Time-consuming obstacles are commonly encountered in the delivery of project interventions. There can be technical difficulties where equipment is to be installed (Hope \& Murphy, 1983). These may relate to the procurement and installation of equipment, as well as to dealing with the rules and regulations that are often associated with purchasing it (Braga, 2002; Bullock et al., 2002; Brown, 2006). 
Braga (2002) noted also that some responses, such as demolishing buildings and changing the use of public space, are lengthy affairs due to the time it can take to identify and contact property owners and plan the specifics of such works.

\section{Conclusions and Recommendations}

As a key aspect of the police reform agenda, it is clear that there has been significant investment in neighbourhood policing. This has concentrated predominantly on the establishment of neighbourhood based teams 'overall, coverage by Neighbourhood Policing teams (NPTs) has been achieved in neighbourhoods across England and Wales, albeit with varying levels of intensity given demands and neighbourhood profiles' (HMIC, 2008: 4). It is well recognised that this will not be enough to achieve the desired outcomes of improved confidence in policing, improved feelings of safety and the reduction of crime (Innes, 2005; Tuffin et al., 2006).

It is contended that neighbourhood policing will fail unless attention is paid to problem solving as the engine of the neighbourhood policing agenda. Putting problem-oriented policing in place has, as we have shown, been found to be no easy task. Police services have been experimenting with the principles of problem solving since the publication of Goldstein's 1979 article and there is every reason to believe that the delivery of joint problem solving will not be straightforward. Indeed, in their study of the early widespread implementation of neighbourhood policing in England and Wales, Quinton and Morris (2008) highlighted how lack of effective problem solving was an issue for almost all sites in their evaluation and noted that it was particularly difficult to implement. In their 2008 review of neighbourhood policing in all police services in England and Wales the policing inspectorate (HMIC 2008: 6) identified 'pockets of good practice for joint problem-solving within forces rather than consistency' and noted that 'the mainstreaming of processes - in understanding joint problem solving and in the systems - is not yet embedded' (HMIC 2008: 36). They summarise the issue as they see it, as follows:

Joint problem solving is developing but there are two major issues. First, there is not a common service-wide approach; and, second, partners are not fully integrated with the neighbourhood policing agenda. Although the latter point is not within the gift of the police service alone, it does, however, offer great opportunity for improving public service. (HMIC, 2008: 6)

This finding comes as no surprise to us. Given its scope and influence, the HMIC inspection report offers a surprisingly small number of recommendations, which are very broad in scope. For example:

ensure that neighbourhood engagement activity is flexible and adapted to local circumstances; and that there is effective profiling of communities, supported through analysis, to gather views, understand and then meet local community and individual need.

It suggests that police services

take stock of the strength and breadth of the current support and guidance to ensure that there is consistency and best practice in community engagement and joint problem solving across the service and communities. (HMIC, 2008: 7). 
We suggest, on the basis of substantial research on past experience, that there are significant threats to the delivery neighbourhood policing agenda, some of which are indeed emphasised by HMIC. The following seem to us to be crucial if neighbourhood policing is to deliver effective problem solving:

1. Leadership and management: The implementation of problem solving will flounder without strong leadership. HMIC (2008) drew attention to the importance of a senior officer-level lead in facilitating the delivery of neighbourhood policing and noted that all but two forces had senior police officer leads. Management of problem solving at the local level seems more problematic. HMIC (2008) found that levels of supervision vary considerably and raised concerns that high ratios of staff to supervisors would impact on the quality of problem solving. Additionally, it has been seen that embedding problem solving requires flexible performance management structure yet HMIC (2008) noted that performance frameworks in many forces are based on quantity rather than quality of service delivery.

2. Data, analysis and evaluation: Interventions are likely to be poorly targeted and unsuccessful if problems are not understood. Reflecting the many other studies which point to problems in delivering high-quality analysis, HMIC (2008) noted that the nature of 'community intelligence' is not universally understood, nor is the process for its capture, and analysis. They also called for the development evaluation of problem-solving activity and the dissemination of good practice. The issue of dissemination of good practice has been exercised many times over the years. The US response has been to establish the 'POP Center' (www.popcenter.org). This is a web-based gold-mine of resources to facilitate problem solving. Just this kind of detailed and informed help will be needed to steer informative local analysis and strategy development if officers are not going to resort to policing responses.

3. Training: If officers and partners do not understand the principles of problem solving and how to apply them, practice is unlikely to be high-quality. HMIC (2008) has drawn attention to a lack of depth and consistency in joint partnership training. This will have to be remedied if effective neighbourhoodbased problem solving is to become routine.

4. Partnership working: In spite of common-sense foundations, almost universal endorsement at the level of principle, legislative support and more than 20 years of experience, many weaknesses in partnership working are still found. There would seem to have been excessive optimism that the persuasive logic of partnership working can provide a basis for constructive and innovative joint initiatives and that disappointments and frustrations could be ironed out with the provision of guidance and advice for practitioners. Partnership has become a modern shibboleth. Whilst the partnership orthodoxy is in principle probably well grounded, it is crucial that partnership working is recognised as a means to an end that is not always necessary and not always optimal in pursuing solutions to the problems faced by neighbourhoods.

5. Abstraction and sustainability: Read and Tilley (2002) drew attention to the impact that abstraction of officers has on the delivery of problem solving. The issue of abstraction has in fact been considered in the neighbourhood policing framework and, reflecting the aim that teams should be familiar and knowledgeable about a locality, there is a requirement that abstraction be low. 
There would seem to be mixed practice here however. HMIC (2008) noted that 33 forces have explicit abstraction policies, protecting between $75 \%$ and $95 \%$ of the time in which officers are dedicated to their neighbourhoods.

Nevertheless they note 'the challenge in developing other areas of policing, such as protective services, has in a number of cases had an impact on the attention given to neighbourhood policing' (HMIC, 2008: 8). The Policing Green Paper (Home Office, 2008) states that funding for officers for neighbourhood policing teams will be ring-fenced for the next three years, following which the position will be reviewed. Removal of ring-fencing is likely to have significant implications for practice and would probably represent the final nail in the coffin for the delivery of this approach.

Skogan advises us, at the start of this article, that, 'it is necessary to be clear-eyed about the difficulties of innovating in police organisations'. The purpose of this article has been to deliver on this admonition, specifically in regard to problem solving in neighbourhood policing, with a view to making some modest suggestions for ways in which the police can avoid falling foul of those 'efforts to change the police [which] often fall far short or fail.' As Skogan says, 'reform ... is hard'.

\section{Notes}

1. Neighbourhood policing has grown out of and was informed by the National Reassurance Policing Programme (NRPP), which in turn was driven by the 'signal crime perspective' developed by Dr Martin Innes and his colleagues at the University of Surrey. This proposes that certain incidents, along with the presence of social and physical disorder, influence how people (individually and collectively) perceive their environment and level of security. Police failure to identify and tackle these events, perhaps because they are concentrating on centrally imposed targets or otherwise failing to identify which problems have significance for the public, raises concerns about crime and disorder. It follows that through identifying these 'signals' (by engaging with the public regarding their concerns) and tackling them (in conjunction with partner agencies) perceptions of crime can be improved.

2. The terms 'problem-oriented' and 'problem solving' tend to be used I nterchangeably as they are in this article.

\section{References}

ACPO/Centrex (2006) Practice Advice on Professionalizing the Business of Neighbourhood Policing. Wyboston: Centrex.

Braga, A. (2002) Problem Oriented Policing and Crime Prevention. New York:

Criminal Justice Press.

Brown, R. (2006) 'The Role of Project Management in Implementing Community Safety Initiatives', in Knutsson, J. and Clarke, R. (eds), Putting Theory to Work: Implementing Situational Crime Prevention and Problem-Oriented Policing, Crime Prevention Studies, vol. 20. Cullompton, Devon: Willan Publishing.

Brown, R. and Sutton, M. (1997) 'Problem-Oriented Policing and Organisational Form: Lessons from a Victoria Experiment' Current Issues in Criminal Justice (July): 21-33.

Bullock, K., Farrell, G. and Tilley, N. (2002) Funding and Implementing Crime Reduction Projects, Home Office Online Report 13. London: Home Office. 
Bullock, K. and Tilley, N. (2003) 'Problem-Oriented Policing: The Concept, Implementation and Impact in the UK and USA', in Bullock, K. and Tilley, N. (eds), Crime Reduction and Problem-Oriented Policing. Cullompton, Devon: Willan

Publishing.

Bullock, K., Erol, R. and Tilley, N. (2006) Problem-Oriented Policing and Partnership. Cullompton, Devon: Willan Publishing.

Byrne, S. and Pease, K. (2003) 'Crime Reduction and Community Safety', in Newburn, T. (ed.), Handbook of Policing. Cullompton, Devon: Willan Publishing. Cordner, G. and Perkins Biebel, E. (2005) 'Problem-oriented Policing in Practice' Criminology and Public Policy 4(2): 155-80.

Eck, J. (2003) 'Police Problems: The Complexity of Problem Theory, Research and Evaluation', in Knutsson, J. (ed.), Problem-Oriented Policing from Innovation to Mainstream, Crime Prevention Studies, vol. 15. Cullompton, Devon: Willan Publishing.

Eck, J. and Spelman, W. (1987) Solving Problems: Problem-Oriented Policing in Newport News. Washington, DC: Police Executive Research Forum. Gilling, D. (2005) 'Partnership and Crime Prevention', in Tilley, N. (ed.), The Handbook of Crime Prevention and Community Safety. Cullompton, Devon: Willan Publishing.

Goldstein, H. (1979) 'Improving Policing: A Problem-Oriented Approach' Crime and Delinquency (April): 236-58.

Goldstein, H. (1990) Problem-Oriented Policing. New York: McGraw-Hill. Goldstein, H. (2003) 'On Further Developing Problem-Oriented Policing: The Most Critical Need, The Major Impediments and a Proposal', in Knutsson, J. (ed.), Problem-Oriented Policing: From Innovation to Mainstream. Crime Prevention Series, vol. 15. Cullompton, Devon: Willan Publishing.

HM Inspectorate of Constabulary (HMIC) (2000) Calling Time on Crime: A Thematic Inspection on Crime and Disorder Conducted by Her Majesty's Inspectorate of Constabulary. London: Home Office.

HM Inspectorate of Constabulary (HMIC) (2008) Serving Neighbourhoods and Individuals: A Thematic Report on Neighbourhood Policing and Developing Citizen Focus Policing. London: Home Office.

Hoare, M.A., Stewart, G. and Purcell, C.M. (1984) The Problem Oriented Approach: Four Pilot Studies. Metropolitan Police, Management Services, Department Report No. 30/84.

Home Office (2000) Review of Crime Statistics: A Discussion Document. London: Home Office.

Home Office (2008) From the Neighbourhood to the National: Policing our Communities Together, Policing Green Paper, Cm 7448. London: The Stationery Office.

Homel, P., Nutley, S., Webb, B. and Tilley, N. (2005) Investing to Deliver: Reviewing the Implementation of the UK Crime Reduction Programme, Home Office Research Study 281. London: Home Office.

Hope, T. and Murphy, J. (1983) 'Problems of Implementing Crime Prevention: The Experience of a Demonstration Project' The Howard Journal 22: 38-50. Innes, M. (2005) 'What's Your Problem: Signal Crimes and Citizen-Focused Problem-Solving' (Reaction Essay) Criminology and Public Policy 4(2): 187-200. Irving, B., Bourne, D. and Collins, J. (2001) Crime Tracking: Developing a Community Safety Intelligence System for the West Ham and Plaistow New Deal Programme. London: Police Foundation. 
Irving, B. and Dixon, B. (2002) Hotspotting. London: Police Foundation.

Knutsson, J. (ed.) (2003) Problem-Oriented Policing: From Innovation to Mainstream, Crime Prevention Series, vol. 15. Cullompton, Devon: Willan Publishing.

Leigh, A., Read, T. and Tilley, N. (1996) Problem-Oriented Policing: Brit POP, Crime Prevention and Detection Paper 75. London: Home Office.

Leigh, A., Read, T. and Tilley, N. (1998) Brit Pop II: Problem-oriented Policing in Practice, Police Research Series Paper 93. London: Home Office.

Metcalf, B. (2001) 'The Strategic Integration of POP and Performance Management:

A Viable Partnership?' Policing and Society 11: 209-34.

Phillips, C., Jacobson, J., Prime, R., Carter, M. and Considine, M. (2002) Crime and Disorder Reduction Partnerships: Round One Progress, Police Research Paper 151. London: Home Office.

Quinton, P. and Morris, J. (2008) Home Office Online Report 01/08. Neighbourhood policing: The Impact of Piloting and Early National Implementation, available online at $<$ http://www.home office.gov.uk/rds/pdfs08/rdsolr0108.pdf $>$ (accessed 6 April 2009).

Read, T. and Tilley, N. (2000) Not Rocket Science?: Problem-Solving and Crime Reduction, Crime Reduction Research Series, Paper 6. London: Home Office.

Scott, M. (2000) Problem-Oriented Policing: Reflections on the First 20 Years.

Washington, DC: US Department of Justice, Office of Community Oriented Policing Services.

Scott, M. (2006) 'Implementing Crime Prevention: Lessons Learned from ProblemOriented Policing Projects', in Knutsson, J. and Clarke, R. (eds), Putting Theory to Work: Implementing Situational Crime Prevention and Problem-Oriented Policing, Crime Preven $\neg$ tion Studies, vol. 20. Cullompton, Devon: Willan Publishing. Skogan, W. (2008) 'Why Reforms Fail' Policing and Society 1: 23-34.

Townsley, M., Johnson, S. and Pease, K. (2003) Problem-Orientation, ProblemSolving and Organisational Change, Crime Prevention Studies, vol. 15. Cullompton, Devon: Willan Publishing.

Tuffin, R., Morris, J. and Poole, A. (2006) Home Office Research Study 296: An Evaluation of the Impact of the National Reassurance Policing Programme. London: Home Office. 